\title{
New perspectives on clinical service after intensive management training
}

\author{
Mark Aveline, Consultant Psychotherapist, Nottingham Psychotherapy Unit, \\ 114 Thorneywood Mount, Nottingham NG3 2PZ
}

\begin{abstract}
An experiment in management training for clinicians in the new NHS

During 1991-2, the Department of Health is spending $£ 3$ million on an experiment. Consultants with an interest in management are being sent to Business School to rub shoulders with middle managers from outside the NHS. Without setting any specific individual objectives, the Department hopes that the acquired learning will be beneficial in the new market-orientated NHS. Together with a community paediatrician, an anaesthetist and a microbiologist, I was selected for a place on the G-course at Ashridge Management College, an intense, four week residential immersion in the theory and practice of profit-driven business.
\end{abstract}

\section{The G-course}

After 27 years in the NHS, it was a novel experience to go back to school and be borne along on the flow of scheduled learning, 'homework' and practicums. Two-thirds of the 38 course-members were from Britain and Ireland, three from Continental Europe and the rest from Africa and the Far East. Together we covered a wide range of product and service industries.

The tutors worked us hard with little let-up at weekends. We were inundated with theory in order to "get us up to speed" for the exercises ahead. A format of being introduced to key concepts, then dividing into small groups to practise what we had learnt, meant that everyone had the experience of working with everyone, a salutary experience when some groups gelled and others failed in their task through rivalry for leadership and lack of collaborative spirit. Small exercises built into large ones lasting days in which we undertook market appraisals or ran simulated businesses.

While I learnt much about finance and accounting, it was marketing and consumer satisfaction and their relationship to quality that most caught my imagination.

\section{Marketing}

I went to Ashridge prejudiced against marketing. A pernicious practice, I felt, intent on making people purchase objects that they neither want nor need. I had to change my mind. The first step in good marketing is finding out what the customer needs and the second is satisfying that need. The word "need" is used advisedly, rather than "want", a more trivial level of desire. Just as in my own work of psychotherapy, understanding how other people see their world and what is important to them is all important. Not only what they value on first thought but, in terms of sales, what they would recognise as being just what they needed if presented with the finished item. In other words, a reaching beyond formulated thought to unmade conclusion.

In the Health Service, we doctors are used to making professional judgements on what would be appropriate courses of action for our patients and juggling the problem against the limit set by our resource. This is a worthy activity; it is doing the best with what we have. Surely we cannot be criticised for that. However the exercise of constructing a 'dream list' of an ideal service highlights fairly easily remedied deficiencies. Appropriate treatment is there to be sure but so is prompt, courteous response, the discussion of therapy options and possible ill-effects, flexibility in provision of services, information about waiting-times and open access to an expert for queries. Deficiencies in these areas can be readily over-looked unless one takes time to think through one's service from the patient's viewpoint.

\section{Consumer satisfaction}

In the lexicon of the new NHS, the customer is king (actually power resides with the purchasers). While customer is a vapid substitute for the time-honoured term of patient, there is a core of truth in the word. We either do serve or should serve our patients and all the colleagues and other services that legitimately need something from us. In an interdependent service, we are all customers of each other.

"Complaints are a shortcut to consumer satisfaction". "A healthy organisation welcomes complaints". Here are two radical statements. In order to "get better at getting better", another catch-phrase from the gurus of management, you need to know what is going wrong so that you can put it right. For every person who is dissatisfied with the service that they have 
received, only one in twelve complains to the provider but each dissatisfied person on average tells ten others about the fault. Bad news spreads fast. If you field the complaint and rectify it, the complainant will sing your praise to five others. This is good publicity for improved service.

Ashridge practised what it preached. It was a pleasure to be in a well-staffed, well-run establishment that took pride in the quality of its service. A small incident, one among many, showed me that being dissatisfied and not complaining in the polite English way was self-defeating. Having silently grumbled for several days, I asked for treacle one breakfast and it was duly provided. What impressed me was it was there each morning thereafter. I was pleased and the staff were pleased by my being pleased. Most people like to do a good job. Instead of being defensive, a circle of satisfaction was completed. The essential element was the willingness of the organisation to hear and respond, a giddy sensation for one accustomed to the new NHS in which professional opinion is often ignored.

\section{Quality}

A fascinating film 'Who Lost the Contract?' showed how minor failings in delivery, reception, preparation for a demonstration of a product and customer relations combined to create such an unfavourable impression that the customer placed his business elsewhere. No one person lost the contract; the effect was cumulative. Quality is everybody's business. The employees of the most successful businesses in recent times in Japan and the USA have a strong shared sense of what they are trying to achieve, are aware of how their role contributes to the whole, are encouraged to innovate in their area of responsibility, and have their expertise listened to. This leads to the internal motivation, dreamed of by managers and so much more powerful a determinant of high quality than the external motivators of money and discipline. For me, the idealism that drives many in the NHS is a priceless asset, not to be lightly squandered.

Quality, we were told, pays in the long-term (provided, of course, that the purchasers want a high quality product as indeed I do hope is the aspiration of the funders of the NHS). To gain high quality, attention has to be paid to critical success factors and getting them right first time. Each service is only as strong as its weakest link at any one time. The good service in getting an assessment done speedily is lost if the report is not sent out equally speedily. All the fine clinical expertise is for nothing if the patient gets lost in the administrative system and so on. Pragmatically, correcting an error early on is easy; later, it can be a major task.

\section{Deficiencies in the course}

It was probably asking too much but I would have welcomed some examination of the defects of the competitive, profit-driven model of business. It is clear that the mind is powerfully concentrated by the necessity of having a positive bottom-line on the profit and loss account when on that fact hangs having a job and staying in business. But competition is inherently wasteful. The competitive model leads to duplication of services (until one provider is victorious in the battle for market share), inhibits collaboration between providers (a good feature of the old NHS), incurs substantial expense in costing and billing, and extracts a toll in disrupted lives when businesses fail. 